\title{
A review of recruitment of children to randomised clinical trials in the NIHR clinical research network portfolio
}

\author{
Geetinder Kaur ${ }^{1 *}$, Rosalind Smyth², Paula Williamson ${ }^{1}$ \\ From 2nd Clinical Trials Methodology Conference: Methodology Matters \\ Edinburgh, UK. 18-19 November 2013
}

\section{Background}

Recruitment of children to randomised clinical trials is perceived to be difficult, although empirical evidence is lacking. We have undertaken a review of recruitment to paediatric trials in the National Institute of Health Research (NIHR) portfolio to understand the current situation and investigate factors that influence recruitment.

\section{Methods}

Randomised clinical trials of any health care intervention, conducted between 2006 and 2012 and closed to recruitment, were identified. Recruitment performance was assessed by comparing achieved to planned recruitment. Putative factors affecting recruitment will be tested for association with successful recruitment, defined initially as recruitment to $100 \%$ of target in the planned time frame. Five factors were selected from an evidence based list of potential factors affecting recruitment; being an IMP (Investigational medicinal product) vs. non-IMP trial, trial of acute vs. chronic illness, CTU support, pilot or feasibility assessment and logistical burden of the trial as compared to routine care.

\section{Results}

152 trials were identified. 52 trials did not meet the inclusion criteria and were excluded. $42 \%$ trials recruited successfully. $66 \%$ of the trials were IMP (Investigational medicinal product) trials and $34 \%$ were non-IMP trials. Preliminary analysis showed no statistically significant association between recruitment success and being an IMP trial $(\mathrm{p}=0.69)$. Full results will be reported.

'University of Liverpool, Liverpool, UK

Full list of author information is available at the end of the article

\section{Conclusion}

This study will provide a quantitative assessment of recruitment performance in paediatric trials and identify predictors of successful recruitment. This information will be very useful in developing strategies to counter the problem of under-recruitment in paediatric research.

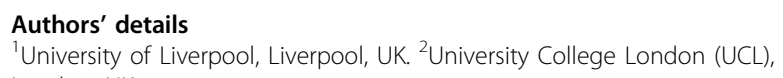

Published: 29 November 2013

doi:10.1186/1745-6215-14-S1-P84

Cite this article as: Kaur et al: A review of recruitment of children to randomised clinical trials in the NIHR clinical research network portfolio. Trials 2013 14(Suppl 1):P84.

Submit your next manuscript to BioMed Central and take full advantage of:

- Convenient online submission

- Thorough peer review

- No space constraints or color figure charges

- Immediate publication on acceptance

- Inclusion in PubMed, CAS, Scopus and Google Scholar

- Research which is freely available for redistribution 